\title{
Mistresses, mothers, and headscarves: media representations of women in corruption scandals in Indonesia
}

\section{Kanti Pertiwi \& Teguh Wijaya Mulya}

To cite this article: Kanti Pertiwi \& Teguh Wijaya Mulya (2022): Mistresses, mothers, and headscarves: media representations of women in corruption scandals in Indonesia, Feminist Media Studies, DOI: 10.1080/14680777.2022.2042832

To link to this article: https://doi.org/10.1080/14680777.2022.2042832

曲 Published online: 02 Mar 2022.

Submit your article to this journal $๘$

Q View related articles $\sqsubset$

View Crossmark data 


\title{
Mistresses, mothers, and headscarves: media representations of women in corruption scandals in Indonesia
}

\author{
Kanti Pertiwi iD $^{\text {a,b }}$ and Teguh Wijaya Mulya $\mathbb{D D}^{\mathrm{c}}$ \\ aepartment of Management, Universitas Indonesia, Depok, Indonesia; ${ }^{\mathrm{b}}$ Department of Management and \\ Marketing, The University of Melbourne, Melbourne, Victoria, Australia; 'Faculty of Psychology, University of \\ Surabaya, Surabaya, Indonesia
}

\begin{abstract}
This article engages with the ways through which women were discursively represented in media reports on corruption cases in Indonesia. Moving away from the traps of universalism and essentialism in conceptualising the causes and consequences of corruption, we unpack the dominant views and contextualise corruption in local-historical perspectives. Our main argument is that gendered meanings around women and corruption in Indonesian news media were constituted through the dominant religious and sociopolitical discourses; and the consequences were the (re)productions of stereotypical and simplistic meanings around women and corruption. Employing critical discourse analysis on 547 selected Indonesian newspaper articles reporting corruption scandals from 2010 to 2020, we identified three key discourses through which meanings around corruption and women were constituted, namely, a discourse of promiscuous sexuality, a discourse of moral ibuism, and a discourse of Islamic piety. The analysis drew attention to the importance of situating corruption and gendered media representation as an intersecting problem embedded in the social, political, religious, and historical contexts; as opposed to the dominant universal, objective, and positivist approaches to corruption studies.
\end{abstract}

\section{ARTICLE HISTORY}

Received 10 August 2021

Revised 6 February 2022

Accepted 10 February 2022

\section{KEYWORDS}

Corruption; gender; media; discourse analysis; Indonesia

\section{Introduction}

The current study problematised the gendered representation of women in corruption scandals in Indonesian news media from a feminist perspective and methodology. It joins contemporary feminist scholarship that have sought to unearth how gendered injustices were perpetuated against women through media representations, particularly how women in crime scandals were distortedly spotlighted and discursively blamed to the extent that it shifted public attentions from the male perpetrators (Elizabeth K Carll 2005; Sara Niner, Yarina Ahmad and Denise Cuthbert 2013); and more importantly, how such representations obscured the larger patriarchal and socio-political structures operating underneath corruption cases. Indonesia is a Southeast Asian Muslim-majority country that has been struggling to democratise itself since the downfall of Suharto's authoritarian regime in 1998. Since then, tensions between progressive socio-cultural discourses such 
as gender equality and traditionally conservative ones such as the pervasive patriarchy endorsed by Suharto were perceptible in the media and everyday life. One of the contentious subjects is the role of women vis-à-vis morality, including in crime cases such as corruption-an issue that has been a major political concern in Indonesia since the late 1990s.

Anti-corruption in Indonesia "erupted" in the late 1990s (Heather Marquette 1999; Mois"é"és. Naím 1994), following the Asian financial crisis and the departure of the late Suharto from the presidency in 1998. Suharto regime and his "crony capitalism" were often deemed to be the primary cause of Indonesia's collapse in the media and public discourse (Catherine H. Lee 2003). In the aftermath of this financial crisis, Indonesia's economies collapsed and resulted in the establishment of various reforms following the assistance from transnational bodies, such as the International Monetary Fund and the World Bank. In their published documents, these bodies often refer to corruption as "cancer" and "moral decay" (World Bank 2003, p .6), suggesting that corruption happens due to "individual moral deficiencies" (World Bank 2003, p .4). Corruption has since been widely seen as a primary cause of the devastating crisis and political turmoil (Rodney Bruce Hall 2003). In mainstream political discourse and everyday public conversations, corruption continues to be seen as a problem of individual morality, that is, caused by "bad apples"-overlooking other structural issues such as inequality and the broader context of postcolonial (under)development (William De Maria 2008; Heather Marquette 2004). Two decades on Indonesia has lived through the so-called democratisation era in which anti-corruption initiatives have become one of the key agendas (Paul K. Gellert 2015).

A major milestone in Indonesia's anti-corruption movement was the establishment of the Corruption Eradication Commission (KPK) in 2002. It took 5 years after the end of the Suharto regime, and strong pressure from powerful donors such as the International Monetary Fund, for KPK as an independent body to begin its operation, even though the anti-corruption law itself was already enacted in 1999 (Vishnu Juwono 2015). The World Bank, as the leading actor in the global anti-corruption campaign, is one of the first to suggest that there was a link between gender and corruption (Helena Stensöta and Lena Wängnerud 2018). In recent years, the anti-corruption drive in Indonesia has turned its attention towards the role of women in supporting the anti-corruption effort, as exemplified in a campaign titled "Saya, Perempuan Anti Korupsi (SPAK)" or "I am a Woman Against Corruption" (The Jakarta Post, December 15, 2015). Such claims are underpinned by research that suggests women have higher ethical standards than men (Andrew C Eggers, Nick Vivyan and Markus Wagner 2018), and that their presence in politics may reduce corruption (David Watson and Amy Moreland 2014).

Against this backdrop, this study engages with the ways through which women were discursively represented in media reports on corruption cases in Indonesia. Moving away from the traps of universalism and essentialism in conceptualising the causes and consequences of corruption, it aims to explore how the relationship between women and corruption is constructed in the news media-an important platform for shaping public opinion over controversial issues. Predicated upon the premise that meanings are contextually and historically constructed, we unpack the dominant views and contextualise corruption in local perspectives. Our main argument is that gendered meanings around women and corruption in Indonesian news media were constituted through the 
dominant religious and socio-political discourses; and the consequences were the (re) productions of stereotypical and simplistic meanings around women and corruption. In so doing, we draw attention to the importance of situating corruption and gendered media representation as an intersecting problem embedded in the social, political, religious, and historical contexts.

The article begins with a review of the literature on corruption, women, and media representation in which we discuss how the current study is built on and contributes new insights to relevant areas of research. We then provide a brief contextual introduction to the socio-political-cultural context of contemporary Indonesia vis-à-vis corruption, morality, and gender. After some methodological notes, we discuss three dominant discourses through which women and corruption were represented by Indonesian news media, namely, a discourse of promiscuous sexuality, moral ibuism, and Islamic piety.

\section{Literature review: corruption, women, and media representation}

The current study is built on and seeks to contribute to three specific areas of research. The first is media representation of women in crime cases, particularly as offenders. Studies in this area have repeatedly identified three predominant characterisations of female offenders, namely, "bad," "mad," and "sad" (Tia Stevens Andersen, Jennifer Silcox and Deena A. Isom Scott 2021; Charlotte Barlow 2020; Rachael E Collins 2016). The "bad woman" character portrays a female offender as intentionally evil, manipulative, dangerous, and ruthless - a femme fatale. The "mad woman" is represented as irrational, monstrous, and unable to control her emotion, obsession, or jealousy. The "sad woman" is pictured as a sympathetic character, a victim of circumstances-poor, battered, or oppressed-who committed crime out of desperation. These characterisations may not be clearly separated, as there is evidence of combinations and in-between positions between these three portrayals (Tua Sandman 2021). Feminists have criticised these limited and simplified representations of female offender as reproducing stereotypical understanding of women (Lorana Bartels, Lorana Bartels, et al. 2015), which resulted in more lenient sentences for some (i.e., "chivalry hypothesis," e.g., Roland V. Landor and Susana A. Eisenchlas 2012) and harsher punishments for others (i.e., "the pedestal effect," e.g., Larissa S Christensen 2018). However, we identified at least two gaps within this scholarship. Firstly, most of these existing studies were conducted in Western settings; we argue that Global South contexts might have different discursive positioning of women in crime cases. In Indonesia, for example, rationalist and psychiatric discourses positioning women as "mad" may not be as dominant as religious discourses in constructing meaning around women's morality. Secondly, most of these previous studies examined media reports on certain criminal cases, mainly murder and sexual abuse. By researching corruption cases, we expand the scholarship in this field since corruption might have a slightly different cultural and gendered dynamics as compared to murder and sexual abuse-like greed and materialism —and thus, producing different subject positions for women involved in this crime. In corruption cases, individual "victims" are also virtually non-existent; almost everyone involved in corruption cases are offenders, including beneficiaries and cronies.

The second area of research we seek to contribute to is the intersecting field of gender and corruption studies. Initiated by the now-classic work of David Dollar, Raymond Fisman and Roberta Gatti 2001 and Anand Swamy, Anand Swamy, et al. 2001, studies on gender and 
corruption have hitherto focused on the persistence of the data supporting "more women, less corruption" hypothesis (Helena Stensöta and Lena Wängnerud 2018). While proponents of this hypothesis consider women as the more ethical and less corrupt gender, opponents of the hypothesis argue that institutional and situational factors play more important roles than gender to explain the ostensibly persistent data (Monika Bauhr and Nicholas Charron 2021; Justin Esarey and Gina Chirillo 2013; Hung-En. Sung 2003). Complementing these main quantitative and positivist studies, some scholars have employed qualitative methodologies and taken into account contextual factors in corruption studies. A key work in this regard is Qi Wang and Dongchao Min 2014 analysis of gender and corruption in China, where they demonstrated how China's transition from socialism to market economy, and uneven distribution of political and economic resources benefitting rich, powerful, male government officials have driven female officials into corruption. Highlighting how women used their sexual appeal and corruption to compete in the changing labour market and get their share of the "cake" in China's growing wealth, Wang et al. (2014), however, did not intently question the traditional gendered norms shaping the dynamics of corruption in contemporary China. To the best of our knowledge, only Qi. Wang 2006 very short article purposely criticised gender inequalities in corruption cases, but the length of her article did not allow an elaborate discussion, let alone adequate evidence. Identifying how this intersecting field of gender and corruption studies are actually lacking in feminist critiques and emancipatory methodologies, we aim to fill this gap by analysing corruption cases in Indonesia using a qualitative, discursive, and feminist approach.

The third and final area of research we built upon and contribute to is corruption studies more generally. The dominant rationalist-universalist-individualist approach in mainstream corruption studies has attempted to explain corruption through the assumptions of fixed meaning, objective identification, atomistic behaviour, and individual(-ised) morality (Kanti Pertiwi 2018). Understanding corruption through such rationalistic terms, corruption is considered as the result of rational agents exercising their rational thinking to maximise individual gains. This perspective, however, detached the individual from their discursive, socio-political situations-including gender norms. As a result, anti-corruption measures are often theorised and practiced through universal principles of good governance (at structural level) and personal integrity (at individual level). Contemporary scholars in this field have called for a new understanding of corruption as a phenomenon embedded in cultural, political, and historical contexts (Davide Torsello and Bertrand Venard 2016). We respond to this call by offering a nuanced analysis of the contextual dynamics of corruption, which renders visible the gendered meaning-making through media representations in a context where various dominant socio-political discourses constitute women as moral subjects. To help readers understand the context of the current study, the next section briefly introduces Indonesia vis-à-vis corruption, politics, and women.

\section{Post-Authoritarian Indonesia: anti-corruption, individual morality, and gender}

As mentioned, the anti-corruption movement in Indonesia has intensified since the start of the reform era in 1998. In the early phase, the anti-corruption efforts were focused on establishing KPK and generating sufficient public support. Several programs have been established within the country to remove the "illnesses" of corruption for Indonesia to 
achieve economic prosperity, so the dominant argument goes. There is a strong emphasis on individual morality in the dominant anti-corruption discourse which can be traced back to earlier texts produced by powerful actors in the field, such as the World Bank and Transparency International (Tara Polzer 2001). In the last two decades, Indonesia's anticorruption became associated with international donor agenda (Gordon Crawford 2003), and in 2013, has taken up gender as one of its central themes.

Gender is a contentious topic and has a long history in the Indonesian academic and public discourse. The main and enduring ideology has been of that which is called "state ibuism" (ibu = mother) (Julia I. Suryakusuma 1996)—a gender ideology developed during the leadership of former president Suharto which glorified Indonesian women as wives and mothers. It manifested in various social, political, and institutional engineering of women, such as Dharma Wanita, a state-sanctioned organisation for the wives of civil servants. Texts and talks that permeated public discourse during that time had been designed towards promoting the nationalist, developmentalist, and anti-communist agenda of the regime, which provided limited space for advocating gender equality. This situation has somewhat changed in the post-1998 democratic era, and resulted in various tensions amongst different political groups (e.g., Siti Aisyah 2012;Kurniawati Hastuti Dewi 2020; Erni Wulandari and Rini Fidiyani 2018). A recent example is the gender-related discursive tensions that were most visible in the 2019 elections (Kurniawati Hastuti Dewi 2020), when two presidential candidates exploited the competing camps by mobilising different narratives around women and motherhood under the slogans "the power of emak emak" (the power of mothers) versus "ibu bangsa" (mother of the nation). The former slogan was popularised by Prabowo Subianto and was associated with working-class mothers in which Prabowo consistently talked about their everyday problems, such as the rising price of basic goods. In contrast, "ibu bangsa" identified more with middle-class women, and Joko Widodo, the incumbent, claimed to be promoting "nationalist" values throughout his campaigns. Despite these seemingly stark differences, both campaigns consistently drew on motherhood identity to win support from women as well as the broader public by reproducing some forms of state ibuism.

\section{Methodological notes}

This article is premised on the understanding that social reality is brought into being through texts and talks, which can be referred to as discourse (David Grant, et al. 2004). A critical discourse analysis approach on corruption allows the unpacking of corruption in terms of its fluid and varied meanings and how shared norms and identities give shape to these meanings. The current study focuses on media discourse because the news media influences public opinion on controversial issues, including corruption (Annette Risberg, Janne Tienari and Eero Vaara 2003). The media as a "sphere of cultural reproduction" (Karen Lumsden and Heather Morgan 2017, 930) does not reflect reality; they (re)construct it, underpinned by particular ideologies (Roger Fowler 2013). The media also becomes an important site in assigning particular meanings using various linguistic devices to achieve certain outcomes. This also means that we are not interested in the technical aspect of language use but on the broader social implications of it. 
More specifically, the methodology of the current study was informed by the literature on feminist media analysis (e.g., Elizabeth K Carll 2005; Alison Harvey 2020; Liesbet van Zoonen 1994). With regards to gender, the media is significant for its symbolic power in (re)producing moral judgments regarding men and women and maintaining the status quo of the dominant group (Lumsden et al. 2017). Contemporary feminist media analyses have demonstrated how patriarchal ideologies are operating in our social, material, and symbolic realities; and what the consequences are for women and other marginalised groups (Dustin Harp, Jaime Loke and IngridBachmann 2018). By analysing the gendered representations in the media as we did in the current study, feminist scholarships are involved in the discursive contestation of power relations in the increasingly mediatised realms that are continuously shaping contemporary social practices and subjectivities, including in the representation of women in corruption scandals-a field of study currently lacking in feminist analysis.

The analysis presented in this article is based on a critical examination of selected Indonesian newspaper articles retrieved from the database Factiva using several criteria. First, we collected articles that contain the word corruption (korupsi), woman (perempuan), and suspect (tersangka), to focus on coverage of scandals. Scandals are important because they tend to trigger media reports and are helpful in terms of their "vivid" constructions of corruption, therefore, suitable for analysis. This initial search generated 377 articles consisting of news reports or headlines published in Indonesia from 2010 to 2020 in different media outlets. This period is particularly relevant because this is when anti-corruption efforts intensified and various scandals emerged. The primary sources of newspaper articles were Tempo.co (97 articles), Suara Pembaruan (82 articles), Tempo Magazine (61 articles), Jawa Pos National Network (58 articles), Investor Daily (31 articles), Koran Tempo (25 articles), and others (23 articles). Selected outlets, particularly from the Tempo Group, are significant because they tend to be more critical towards the government while targeting middle-upper class audiences. We later collected more articles to enable a deeper analysis of the following highly publicised scandals: Miranda Goeltom, Ratu Atut, and Angelina Sondakh, which resulted in 170 additional articles from a variety of newspapers. The total number of articles analysed is 547 .

The analysis was carried out in two stages. First, we started by closely reading each article in chronological order to identify initial categories. To help with our analysis, we asked questions such as: How is corruption described in the scandals? Who is involved and how? How is corruption described in relation to women? What roles were attached to each person involved in the case? What linguistic expressions are used? How are women implicated in scandals described in relation to men? We also paid more attention to news covering highly publicised scandals that visibly involve the relationship between men and women (see Table 1). In the second stage, we developed a summary of important themes that appear in each of the articles and noted several of the recurring ones that lend themselves to discerning the portrayal between (anti)corruption and women. We engage in an iteration process by reading articles focusing on a particular scandal, comparing articles between scandals, and reading all articles as a whole. 
Table 1. Highly publicised corruption scandals involving women.

\begin{tabular}{|c|c|c|c|}
\hline No. & Year & Scandal & Description \\
\hline 1 & 2012 & Nunun Nurbaeti & $\begin{array}{l}\text { Nunun Nurbaeti was sentenced to two years and six months in prison for bribing } \\
\text { lawmakers at the House of Representatives in the } 2004 \text { election and the Bank } \\
\text { Indonesia (BI) senior deputy governor. }\end{array}$ \\
\hline 2 & 2012 & Miranda Goeltom & $\begin{array}{l}\text { After three years of investigation, Miranda, a professor of monetary economics at the } \\
\text { University of Indonesia, was sentenced to three years in prison for bribing } \\
\text { lawmakers to elect her as senior deputy governor at the central bank in } 2004 \text {. }\end{array}$ \\
\hline 3 & 2012 & Atut Chosiyah & $\begin{array}{l}\text { Atut was sentenced to a seven-year prison term for bribing then Constitutional Court } \\
\text { chief justice Akil Mochtar over an election dispute in Banten in } 2013 \text {. }\end{array}$ \\
\hline 4 & 2014 & Wawan & $\begin{array}{l}\text { Wawan or Tubagus Chaeri Wardana was found guilty of having bribed disgraced ex- } \\
\text { Constitutional Court chief justice Akil Mochtar, for a favourable ruling in the Lebak } \\
\text { regency election dispute being heard by the Constitutional Court. }\end{array}$ \\
\hline 5 & 2013 & $\begin{array}{l}\text { Fathanah/PKS- } \\
\text { Beef-gate }\end{array}$ & $\begin{array}{l}\text { Businessman Ahmad Fathanah was sentenced to } 14 \text { years behind bars for his role in } \\
\text { a corruption case centring on beef import quotas at the Agriculture Ministry and his } \\
\text { involvement in money laundering. }\end{array}$ \\
\hline 6 & 2015 & Angelina Sondakh & $\begin{array}{l}\text { Former beauty queen Angelina was sentenced to } 10 \text { years in prison after she was } \\
\text { found guilty in corruption cases at the Education Ministry and Youth and Sport } \\
\text { Ministry. }\end{array}$ \\
\hline 7 & 2017 & Atut Chosi) & $\begin{array}{l}\text { Former Banten governor Atut was again sentenced to five years in prison for her role } \\
\text { in a graft case surrounding a } 2012 \text { project to procure medical equipment in the } \\
\text { province of Banten. }\end{array}$ \\
\hline 8 & 2018 & Rita Widyasari & $\begin{array}{l}\text { Rita was a non-active Kutai Kartanegara regent when she was sentenced to } 10 \text { years in } \\
\text { prison for her involvement in a bribery case related to various projects in the } \\
\text { resource-rich East Kalimantan regency. }\end{array}$ \\
\hline
\end{tabular}

\section{Findings}

\section{A discourse of promiscuous sexuality: corrupt men and their glamorous mistresses}

The first recurring theme identified in the data is the notion that corrupt Indonesian men were motivated by sexual desire towards women (with their materialistic needs), or to be precise, women who were not their legal spouse. We call this the dominant discourse of sexual promiscuity, in which men are positioned and normalised as providers and sexually promiscuous, and women as financially dependent, seductive, and materialistic. These traditional gendered portrayals tend to reproduce the assumption that women are the ultimate beneficiary of corrupt acts, and therefore responsible for the man's fault.

Some high-profile corruption cases in Indonesian news media attest to this narrative include-among others-Wawan's bribery scandal, Fathanah's beef-gate scandal, and North Sumatra ex-governor Gatot Pujo Nugroho scandal. The media exploited stories surrounding these men's promiscuous relationship with women who are not their wives, or stories about their second wives. For instance, in an article entitled "These are the 45 women who received Fathanah's money," news media discussed at length how the leading man in the beef-gate corruption case distributed his wealth to a significant number of women:

There are also 45 women who are suspected of receiving Fathanah's funds, (some examples are) as follows:

(1) Dewi Kirana: Rp.156 million through BCA 30 times, between March 162,004October 142,005. Rp 6.75 million through BCA, four times, between February 92,004-June 152,005. Rp. 265 million through Bank Mandiri, eight times, between January 12,011-February 12,013. 
(2) Yulia Puspitasari: Rp. 110 million through Bank Mandiri, once, between January 12,011-February 12,013.

(3) Evi Anggraini: Rp. 525 million through Bank Mandiri, three times, between January 1, February 120,112,013, PT. Swakarya Adi Indah. And Rp. 600 million through Bank Mandiri, 12 times.

By putting the sensational number of Fathanah' female beneficiaries in the title, the media drew attention to corrupt men's promiscuous relationships and his alleged "mistresses." It conveys a message that a man - with all the money in his hands-could get any woman he wanted and, however, many he wanted. In addition to the number of women, detailing the sums of money channelled to these "mistresses" gives an impression that they were the main beneficiaries of this corruption case. The news removed the spotlight from the male offender to his materialistic and glamorous "mistresses"-positioning them as the ultimate reason for men's corruption; the man's motivation for corruption became selfexplanatory. This impression fits the wider narrative of men as providers and "naturally" promiscuous, so that it "makes sense" that they committed corruption to please their materialistic and seductive "mistresses." Here, women are positioned as both the starting point and the end point of men's corruption, and therefore, blameworthy.

Further, media reports we analysed also normalise corrupt men's promiscuity by trivially presenting it as a humorous piece. As an example, an article elaborated Wawan's claim that he bought a car for his "grandmother" to disguise the identity of young female actress, Jennifer Dunn, whom he called a "close friend":

According to him, Wawan usually buys cars in large quantities. Then, the purchase was made on behalf of several women who he claimed to be relatives. (Wawan) 'buys in tens. I just found out that Wawan's grandmother's name is Jennifer Dunn, because (it was stated) the car was registered under the name of her grandmother,' said Agus jokingly.

Evoking the stereotypes of celebrity lifestyles, Jennifer Dunn was chosen in this media report among Wawan's "several women" to create an image about the characteristics of these female beneficiaries: physically attractive, glamorous, and high-maintenance women. In so doing, the media (re)produced the discourse of promiscuous sexuality where women are positioned as materialistic and sexually seductive. These traditional gender norms implicated in corruption case reports are, surprisingly, virtually invisible in contemporary studies on gender and corruption, which hitherto focused on "more women, less corruption" hypothesis (e.g., Bauhr et al. 2021; Stensöta et al. 2018). By revealing the operation of this discourse within corruption media reports, we brought back feminist critiques into the intersecting field of gender and corruption studies, and demonstrated how gendered "logics," which put women into stereotypical subject positions, are still extensively drawn upon in representing corruption cases in Indonesia.

\section{A discourse of moral ibuism: women as moral guardians of the nation}

While advocating personal integrity as a cure for corruption has previously been criticised for overlooking structural and institutional constraints (Anja C. Gebel 2012; G W. Walton and Dr Jon S.T. Quah 2016), in this section we offer another angle of critique for the individualised approach to morality in corruption studies, namely, from 
a cultural and feminist perspective. We argue that the notion of personal integrity as the cure for corruption is not simply an individual's moral decision, but rather, morality is constituted through various socio-political-historical discourses unique to each context, and with different ramifications for men and women. However, we found consistent portrayals of women as moral guardians of the family and of Indonesia as a nation, which we refer to as a discourse of moral ibuism. Earlier in this article we have discussed the notion of state ibuism, in which Suharto's (1966-1998) ideological legacy still serves as a dominant discourse in restricting Indonesian women into traditional domestic roles of wives and mothers. Ensuring moral obedience is commonly included as the task of a "good" Indonesian mother, which extends not only of their children and family but of the whole nation. As Sharyn Graham Davies 2018 noted, Indonesian women are to be "moral labour" and they are "expected to undertake various sorts of aesthetic, spiritual, and emotional labour to achieve and present a model moral self" (p. 70).

We found depictions of these "motherly" women, which are in stark contrast with the seductive "mistresses" discussed previously. Here, women were projected as the ones responsible for planting the "seeds of virtue" in the family, and should feel ashamed when a family member is involved in corruption. Simultaneously, women were also blamed for innocently enjoying the fruits of their husband's crime as it showed her naivety and moral weaknesses, such as accepting unusually expensive gifts from their (corrupt) husbands. An exemplary statement illustrates this discourse can be found in the speech of the head of the Indonesian Women's Congress (Kowani), a prominent Indonesian women's organisation cited by a newspaper:

'Women must be good moral cultivators to reduce, filter, and protect against negative things, such as corruption,' said Giwo in Jakarta, Friday.

"..."... she gave an example: if your husband suddenly buys something which price does not match his salary, it is necessary to ask where the money comes from. "..."...'Don't get too excited if he buys you an expensive item,' she said.

As illustrated in the excerpt above, wives are positioned as the moral compass of the family and should hold their husbands accountable for their corrupt conduct. When this idealised moral role of women did not materialise-such as in the case of corruption involving wives and children as cronies-it created media sensation. A news article, discussing a scandal involving a family of fugitives, for example, was entitled "Korupsi yang Beranak-pinak" (Corruption that Reproduces/Breeds/Multiplies), evoking a sense of disgust from the image of uncontrolled animalistic reproductions of a crime (i.e., corruption):

Former KPK Chairperson and KPK Deputy Chair, Busyro Muqoddas called this reality a breeding (beranak-pinak) phenomenon of corruption. "..."...... In the past, there was a family planning (KB) program, now there is a trend towards family corruption (korupsi berkeluarga), which is also abbreviated as KB. "..."..... A legal expert who is now a member of the KPK's Election Committee, Yenti Garnasih, commented that the (increasing) number of women who were involved in corruption "..."..... (are) the carriers of calamities.

Using and juxtaposing the term beranakpinak (breeding) with family planning conveys a pejorative meaning, particularly when contrasted with Indonesia's family planning programme, which was often hailed as successful by international agencies, 
see for example (Ines Smyth 1991). Such linguistic gesture creates a counterintuitive image against the "uncontrollably multiplying corruption," namely, the moral order of a middle-class family that restricts the number of their children through contraception, and successfully educates them into morally obedient citizens. Unsurprisingly, Indonesian family planning has historically been associated with women as wives and mothers, as the types of contraception promoted were mainly female contraception and only legally accessible for married couples. Here, corruption was represented as a problem that originated in the family that could further multiply uncontrollably (beranak-pinak) when women/mothers do not actively take action like in the family planning program. In other words, corruption becomes the responsibility of the family in question, particularly, the women responsible for the morals of the family. When they failed, women were referred to as "carriers of calamities"-carrying and nurturing korupsi berkeluarga (family corruption).

Through this discourse of moral ibuism, the role of women as moral guardians extends further from the family to the nation. Drawing on the imagined notion of "ibu bangsa" (mother of the nation), some news articles we analysed display views, which put the duty to cure corruption on women's shoulders. The term "ibu bangsa" popularised by Joko Widodo during his presidential campaigns in 2019 election defines Indonesian women in the tightly defined space of mothers as educators and the moral shield of family and society (Luky Sandra Amalia 2019). In the case of corruption, women were positioned as the ones who should take the blame for not doing enough to prevent it.

(The head of the Indonesian Women's Congress) emphasised that corruption is a moral problem. Therefore, women as mothers of the nation (ibu bangsa) who give birth to the nation's children must cry (seeing this scandal unfolds) because corruption is the evidence of moral and ethical deviation. "..."..... She is deeply disappointed in corruption convicts who grew up receiving care and blessing from mothers throughout the years but eventually gave in to pragmatic values.

In this quote, women are described in terms of their caring and nurturing abilities, which are in contrast with pragmatic values that give way to corruption. As the nurturing figures and moral guardians, women should lament ("must cry," instead of angry) when looking at the persisting corruptions in the country. The hegemonic view that women are to be mothers and have the sole responsibility of raising good children extends to the idea of a good society where traditional morality prevails. With regard to corruption, women bear the ultimate responsibility because they "have failed to do their part in protecting the sacred values of the past from the onslaught of the present." (Suzanne Brenner 1999, 23).

\section{A discourse of Islamic piety: Muslim women, modesty, and hypocrisy}

The third and final key discourse identified in our analysis is the discourse of Islamic piety in which women implicated in corruption scandal were represented in terms of their outward expression of religiosity and the Islamic value of modesty. As the home of the world's largest Muslim population, Islam has been a significant socio-cultural force constituting ways-of-seeing and ways-of-being of most Indonesians. Corruption has been 
represented as a form of jihad (The Jakarta Post, 9 June, 2019) and those committing it will be severely punished in the afterlife (Kompas, February 7, 2013). The news media in our analysis tended to focus on two religious aspects pertinent to Muslim women, namely, hijab and modesty. A news article entitled "Corruption and Visual Modification" (Sindonews, November 25, 2020) specifically discussed these aspects:

These religious attitudes often differ 180 degree when compared to their appearance before they were caught. In plain view, this change in behavior and appearance is easier for us to see in perpetrators of corruption who happen to be women. Women who are named suspects of corruption (suddenly) wear headscarves or hijab. Before the scandal, it was never like that. They used to wear revealing clothes, even showing off their luxurious lifestyle on social media without a burden.

It has become an increasingly common spectacle in Indonesia that women who were implicated in corruption cases (and other crimes) changed their appearance during court hearings by putting on a headscarf or hijab, which the media generally treated with suspicion and labelled the women who wear them hypocrites. Here, Muslim women's bodies were discursively politicised in ways that offer no way out for these women: wearing hijab is interpreted as hypocrite, not wearing hijab is associated with lack of intention to repent from their past "sins." In the context of rising public piety in contemporary Indonesia (Sharyn Graham Davies 2018), women's religious appearances become intertwined with the perception of their morality, and-for those involved in corruption cases - made them more vulnerable.

The excerpt above also contrasted wearing a hijab with "showing off their luxurious lifestyles" to discursively position materialism as the opposite of the Islamic value of modesty. Modesty has commonly been mentioned as one of the central tenets of Islamic teachings for Muslims' lifestyle (Hanny Savitri Hartono 2018). A "good" Muslim woman is traditionally represented as modest and does not indulge herself in worldly pleasures and consumerism. While this image might have been somewhat contested by the recent surge of the new Muslim middle class (Mundi Mundi Rahayu 2014), the news articles we examined left little room for doubt when portraying how women in corruption cases spend their "illicit wealth" using examples of collecting extraordinarily high-end handbags to luxurious cars. The case of the wife of former Deputy Chief of National Police, Nunun Nurbaeti, is a relevant example:

Nunun is known as a top socialite. She likes to collect ancient fabrics and kebaya (fine traditional clothes), jewellery, and dozens of Hermes bags. "..."..... Nunun's hobby of collecting Hermes bags was confirmed by her friend, Tience Sumartini. 'But I don't know how many there are,' said Tience, as quoted in TEMPO edition 09/39, May 2010.

This vivid portrayal of luxurious lifestyle is consistent with several other news articles (e.g., those titled "Ayu Azhari Keeps Fathanah's Money in Luxury Bags," "Regent Rita Widyasari's 40 Luxury Bags from Gucci to Hermes," "Receiving Gifts of Luxury Bags and Expensive Jewelry, Beautiful Regent Sentenced to 4.5 Years in Prison") which then feed into the belief that corruption happened because of conspicuous lifestyle. Through the dominant traditional view of wives as the ones who control household expenses, the blame is comfortably assigned to women. When women fail, they will fall (or push their husbands) into the trap of corruption. To curb corruption, according to this logic, 
women must practice "living a simple life" (hidup sederhana) or, in Islamic terms, modesty. Such simplistic views on corruption are constituted through a dominant discourse of religious piety:

"..."..... a simple standard of life for state administrators is key to achieve the progress of the nation and the welfare of the people. Unfortunately, many officials are so clever at twisting their tongues (bersilat lidah), so that the various luxury facilities, extravagance, and money given to them still seem reasonable. "..."..... This is because the simple standard of life (hidup sederhana) for state administrators is deliberately obscured by kemunafikan (= Arabicoriginated Indonesian word for hypocrisy with an Islamic nuance).

\section{Discussion and conclusion}

This study has revealed at least three dominant discourses through which women in corruption cases are represented in the media, namely, a discourse of sexual promiscuity, moral ibuism, and Islamic piety. The first discourse of sexual promiscuity speaks to the corruption literature which to date is largely culture- and gender-blind in both theorisations and praxis. Existing anti-corruption initiatives, for instance, have not yet included contextual understandings of socio-cultural norms (Kanti Pertiwi 2020; Kanti Pertiwi and Susan Ainsworth 2020), let alone gender analyses in emancipatory ways; preferring instead, the promotion of good governance and personal morality (Anja C. Gebel 2012). The dominant Western-originated, positivist theorisations of corruption have failed to recognise the role of local cultural norms, for example, the mistress culture operating through the discourse of sexual promiscuity as identified in the current study and also in Wang et al. (2014) study in China. This is most likely because relatively more equal access to the job market between men and women, and unaccepted practice of polygamy have historically limited mistress culture in many Western contexts. In Indonesia, the enduring cultural tropes of "wealth, throne, and women" (harta, tahta, and wanita) as men's greatest achievements as well as greatest tests in life (Desi Dwi Prianti 2019) might have made corruption by men more understandable, although not accepted.

The second discourse of moral ibuism demonstrates that the relationship between corruption and morality does not exist in vacuum (i.e., neutral, objective, or positivist), instead, it is entangled in various socio-political-historical discourses in a specific local context. Using the case of Indonesia, the inertia of the ideology of state ibuism evidently still serves as discursive resources drawn upon by the news media to represent women and corruption. Third, the discourse of Islamic piety highlights how an oversimplified take on women and corruption exemplified by the Nunung case above-one that blamed the individual's moral, religious, and lifestyle choices-has downplayed the more complex relationship between Indonesian state officials and politicians in the era of neoliberal democratic reform (Li Tania Murray 2016; Yuna Farhan 2018) and the hierarchical nature of Indonesians' social relationships as part of its colonial legacy (Desi Dwi Prianti 2018). The news articles we analysed still subscribed to the dominant rationalist approach to corruption (Torsello et al. 2016) which constitutes "corrupt" individuals as people who exploit perks or facilities attached to their positions, and yet, are detached from the broader socioeconomic, cultural, religious, and political realities. Perpetually representing women through a discourse of religious piety in dichotomous modes (modest vs corrupt, pious 
vs hypocrite) might overlook the complexities of women's situations in a corruption scandal. In other words, drawing upon and reproducing the discourse of individual piety and religious morality left the structural problems of corruption remain hidden.

The contributions of this study are threefold. Firstly, unearthing the discourse of moral ibuism in our findings offers an alternative insight for feminist studies on gendered media representation in crime cases which are predominantly Western-based. Typical characterisations of "bad," "mad," and "sad" female offenders within this scholarship (Andersen, Silcox, and Scott 2021; Charlotte Barlow 2020; Rachael E Collins 2016) were generally detached from any cultural and historical contextuality. By connecting Suharto's ideological legacy of state ibuism with contemporary representation of women in corruption cases, we render visible the Western presumed privilege of being unmarked, where analyses of women offenders in the media in previous studies tend to position their findings as cultureless and ahistorical. None of the previous studies in this established field (e.g., Charlotte Barlow 2020; Bartels 2015; Larissa S Christensen 2018; Rachael E Collins 2016; Tua Sandman 2021) have discussed how their analyses were located in specific cultural and historical milieu, namely, the contemporary West. Instead, they claimed the privilege of not needing to explain the cultural and historical contexts of their study, which is in stark contrast with our current study.

Secondly, our study contributes to studies at the intersection of gender and corruption, which rarely employed cultural and feminist analyses (Stensöta et al. 2018). Taking a feminist perspective at the heart of our analysis enabled an identification of gender injustices within the Indonesian media representation of corruption cases, in which stereotypical subject positions available for women in this context rendered them morally blameworthy. Echoing Niner et al. (2013) who studied media representations of child abuse in Malaysia, we call for a deeper collaboration between scholars, feminists and women advocates to develop a more culturally sensitive analysis of controversial practices such as corruption and question the invisibility of men in their perpetuation. Furthermore, by identifying how the discourse of Islamic piety underpinned the media representations, our analysis extends contextual theorisations of the intersection between gender and corruption in the Global South. While Wang et al. (2014) study in China, for instance, has identified how China's neoliberal transition to market economy and the persistence of mistress culture might have played a role in Chinese women's involvement in corruption, religions are virtually missing from their analysis because, most likely, of the relatively religion-less contexts of contemporary China. Using discourse analysis to analyse corruption in Indonesia, we brought religion into the mix, and further demonstrated the importance of recognising local social, historical, and political contexts in which women are situated.

Thirdly, our overall analysis contributes insights to broader (anti)corruption scholarship and praxis by demonstrating that the relationship between women and corruption cannot be separated from its contextual situatedness-culture, politics, and history. To quote (Gellert (2015), 382), "the problems of 'entrenched corruption' are not simply ones of individual morality and educating citizens properly." To solve corruption, one must attend not only to the complexities of the bureaucratic and legal systems (Marcus Mietzner 2015) but also the broader political economy structures-and if we may add, gendered and cultural norms-including the idea that ethical failures are rooted in women's failures (Niner et al. 2013). 
Corruption studies must interrogate the broader patriarchal and moral system, which encourages and tends to normalise wealth accumulation through questionable practices.

The implication of this study is that anti-corruption campaigners and the media need to develop and arrive at more meaningful ways to change social practices commonly labelled "corruption" that would not in any way be discriminatory against women. While there is no simple panacea in this regard, avoiding the reproduction of stereotypical images of women in corrupt cases could be a small step in that direction. Future studies are needed to explore further alternative discourses through which women in corruption cases may be represented in more emancipatory ways. For instance, in what ways Islam as a key socio-cultural force in Indonesia might provide discursive resources to destabilise the hegemonic views on women and corruption? Furthermore, a specific study focusing on the discourse of the anticorruption campaign targeting women, "I am a Woman against Corruption" (Saya, Perempuan Anti-Korupsi), is also warranted. Finally, future researchers need to think of more inclusive ways to present women's viewpoints about (anti)corruption as a lived experience. In our data, there were some "traces" of such viewpoints, for example, a court hearing presenting female politician Angelina Sondakh showed that she saw herself as "debu di bawah keset" or "dust under the doormat" (Intan Umbari Prihatin 2016), suggesting that women in her position in the political party, far from being the mastermind, are actually being exploited by men in corrupt dealings. Such viewpoint can further be explored through interviews or ethnography - one that is embedded in social, economy, cultural, and political contexts, and lends women a greater sense of agency in making meaning out of their experiences.

\section{Acknowledgments}

We thank Dr Hani Yulindrasari for her feedback in an earlier draft.

\section{Disclosure statement}

No potential conflict of interest was reported by the author(s).

\section{Funding}

This research is partially funded by Universitas Indonesia through the PPI (Pendamping Publikasi Internasional) Q1 funding scheme. (Grant number: NKB-627/UN2.RST/HKP.05.00/2021).

\section{Notes on contributors}

Kanti Pertiwi is an Assistant Professor in Organisation Studies at Universitas Indonesia and an Honorary Fellow at the University of Melbourne. She previously worked for the Indonesian Corruption Eradication Commission. Her research interests include organisational discourse, ethics, gender, and public administration. Email: kanti.pertiwi@ui.ac.id

Teguh Wijaya Mulya is a Senior Lecturer at the Faculty of Psychology at the University of Surabaya, Indonesia. He specialises in critical research in the areas of sexuality, gender, religion, youth, education, and discourse analysis. His work is inspired by the work of Michel Foucault, poststructuralist feminism, and discourse theories. E-mail: teguh@staff.ubaya.ac.id 


\section{ORCID}

Kanti Pertiwi (iD http://orcid.org/0000-0001-9888-7401

Teguh Wijaya Mulya (D) http://orcid.org/0000-0002-8899-1157

\section{References}

Aisyah, Siti. 2012. "Rereading Patriarchal Interpretations on the Qur'an from Hadith Perspective in the Eve of Law No. 23/2004 on the Elimination of Domestic Violence." Journal of Indonesian Islam 6 (1): 48-75. doi:10.15642/JIIS.2012.6.1.48-75.

Amalia, Luky Sandra. 2019. “Upaya Mobilisasi Perempuan Melalui Narasi Simbolik 'Emak-emak Dan Ibu Bangsa'Pada Pemilu 2019." Jurnal Penelitian Politik 16 (1): 17-33. doi:10.14203/jpp. v16i1.779.

Andersen, Tia Stevens, Jennifer Silcox, and Deena A. Isom Scott. 2021. "Constructing "Bad Girls": Representations of Violent Girls in the Canadian and U.S. News Media." Deviant Behavior 42 (3): 353-365. doi:10.1080/01639625.2019.1676105.

Barlow, Charlotte. 2020. "Gender and Crime News: Female Offending/CoOffending." In The International Encyclopedia of Gender, Media, and Communication, edited by Karen Ross, 1-7. doi:10.1002/9781119429128.iegmc204

Bartels, Lorana, L. Bartels, N. Nelson, and K Holland. 2015. "How are Women Who Kill Portrayed in Newspaper Media? Connections with Social Values and the Legal System." Women's Studies International Forum 51: 31-41. doi:10.1016/j.wsif.2015.04.003.

Bauhr, Monika, and Nicholas Charron. 2021. "Will Women Executives Reduce Corruption? Marginalization and Network Inclusion." Comparative Political Studies 54 (7): 1292-1322. doi:10.1177/0010414020970218.

Brenner, Suzanne. 1999. "On the Public Intimacy of the New Order: Images of Women in the Popular Indonesian Print Media." Indonesia 67: 13-37. doi:10.2307/3351375.

Carll, Elizabeth K. 2005. "Violence and Women: News Coverage of Victims and Perpetrators." In Featuring Females: Feminist Analysis of Media, edited by Ellen Cole and Jessica Henderson Daniel, 143-153. Washington: American Psychological Association.

Christensen, Larissa S. 2018. "The New Portrayal of Female Child Sexual Offenders in the Print Media: A Qualitative Content Analysis." Sexuality \& Culture 22 (1): 176-189. doi:10.1007/s12119-0179459-1.

Collins, Rachael E. 2016. "'Beauty and Bullets': A Content Analysis of Female Offenders and Victims in Four Canadian Newspapers." Journal of Sociology 52 (2): 296-310. doi:10.1177/ 1440783314528594.

Crawford, Gordon. 2003. "Partnership or Power? Deconstructing the 'Partnership for Governance Reform' in Indonesia." Third World Quarterly 24 (1): 139-159. doi:10.1080/713701365.

Davies, Sharyn Graham. 2018. "Skins of Morality: Bio-borders, Ephemeral Citizenship and Policing Women in Indonesia." Asian Studies Review 42 (1): 69-88. doi:10.1080/10357823.2017.1407292.

De Maria, William. 2008. "Measurements and Markets: Deconstructing the Corruption Perception Index." International Journal of Public Sector Management 21 (7): 777-797. doi:10.1108/ 09513550810904569.

Dewi, Kurniawati Hastuti. 2020. "Motherhood Identity in the 2019 Indonesian Presidential Elections." Contemporary Southeast Asia 42 (2): 224-250. doi:10.1355/cs42-2d.

Dollar, David, Raymond Fisman, and Roberta Gatti. 2001. "Are Women Really the 'Fairer Sex'? Corruption and Women in Government." Journal of Economic Behavior \& Organization 46 (4): 423-429. doi:10.1016/S0167-2681(01)00169-X.

Eggers, Andrew C, Nick Vivyan, and Markus Wagner. 2018. "Corruption, Accountability, and Gender: Do Female Politicians Face Higher Standards in Public Life?" The Journal of Politics 80 (1): 321-326. doi:10.1086/694649.

Esarey, Justin, and Gina Chirillo. 2013. "“Fairer Sex" or Purity Myth? Corruption, Gender and Institutional Context." Politics and Gender 9 (4): 361-389. doi:10.1017/S1743923X13000378. 
Farhan, Yuna. 2018. "The Politics of Budgeting in Indonesia." PhD diss., University of Sydney.

Fowler, Roger. 2013. Language in the News: Discourse and Ideology in the Press. London: Routledge. Gebel, Anja C. 2012. "Human Nature and Morality in the Anti-Corruption Discourse of Transparency International." Public Administration and Development 32 (1): 109-128. doi:10.1002/pad.1604.

Gellert, Paul K. 2015. "Optimism and Education: The New Ideology of Development in Indonesia." Journal of Contemporary Asia 45 (3): 371-393. doi:10.1080/00472336.2014.978352.

Grant, David, Cynthia Hardy, Cliff Oswick, and Linda L Putnam. 2004. "Introduction: Organizational Discourse: Exploring the Field." In The Sage Handbook of Organizational Discourse, edited by David Grant, Cynthia Hardy, Cliff Oswick, and Linda Putnam, 1-37. London: Sage Publications.

Hall, Rodney Bruce. 2003. "The Discursive Demolition of the Asian Development Model." International Studies Quarterly 47 (1): 71-99. doi:10.1111/1468-2478.4701004.

Harp, Dustin, Jaime Loke, and Ingrid Bachmann, Eds. 2018. Feminist Approaches to Media Theory and Research. Cham: Palgrave Macmillan.

Harvey, Alison. 2020. Feminist Media Studies. Cambridge: Polity Press.

The Jakarta Post. 2015. "Women Play a Big Role in Preventing Corruption, Ahok Says." December 15. The Jakarta Post. 2019. "Jihad against Corruption." June 19.

Juwono, Vishnu. 2015. "The Partner in Prosecuting Crime: The Role of International Organization in Setting up Corruption Eradication Commission in Indonesia." Global: Jurnal Politik Internasional 16 (1): 1-18.

Kompas. 2013. "Korupsi Itu Bertentangan Dengan Agama." February 7.

Landor, Roland V., and Susana A. Eisenchlas. 2012. "“'Coming Clean" on Duty of Care: Australian Print Media's Representation of Male versus Female Sex Offenders in Institutional Contexts." Sexuality \& Culture 16 (4): 486-502. doi:10.1007/s12119-012-9134-5.

Lee, Catherine H. 2003. "To Thine Ownself Be True: IMF Conditionality and Erosion of Economic Sovereignty in the Asian Financial Crisis." University of Pennsylvania Journal of International Law 24: 875 .

Lumsden, Karen, and Heather Morgan. 2017. "Media Framing of Trolling and Online Abuse: Silencing Strategies, Symbolic Violence, and Victim Blaming." Feminist Media Studies 17 (6): 926-940. doi:10.1080/14680777.2017.1316755.

Marquette, Heather. 1999. "Corruption Eruption: Development and the International Community." Third World Quarterly 20 (6): 1215-1220. doi:10.1080/01436599913370.

Marquette, Heather. 2004. Corruption, Politics and Development. 1st ed. London: Macmillan.

Mietzner, Marcus. 2015. "Dysfunction by Design: Political Finance and Corruption in Indonesia." Critical Asian Studies 47 (4): 587-610. doi:10.1080/14672715.2015.1079991.

Naím, Mois"é"és. 1994. "The Curruption Erruption." The Brown Journal of World Affairs 2 (2): 245.

Niner, Sara, Yarina Ahmad, and Denise Cuthbert. 2013. "The 'Social Tsunami': Media Coverage of Child Abuse in Malaysia's English-Language Newspapers in 2010." Media, Culture \& Society 35 (4): 435-453. doi:10.1177/0163443713483796.

Pertiwi, Kanti. 2018. "Contextualizing Corruption: A Cross-Disciplinary Approach to Studying Corruption in Organizations." Administrative Sciences 8 (2): 12. doi:10.3390/ admsci8020012.

Pertiwi, Kanti. 2020. "'We Care about Others": Discursive Constructions of Corruption Vis-à-vis National/Cultural Identity in Indonesia's Business-Government Relations." Critical Perspectives on International Business ahead-of-print (ahead-of-print). doi:10.1108/cpoib-03-2019-0025.

Pertiwi, Kanti, and Susan Ainsworth. 2020. "“Democracy Is the Cure?": Evolving Constructions of Corruption in Indonesia 1994-2014." Journal of Business Ethics 173 (3) 507-523. doi:10.1007/ s10551-020-04560-y.

Polzer, Tara. 2001. "Corruption: Deconstructing the World Bank Discourse." Development Studies Institute (DESTIN) Working Paper 1: 18.

Prianti, Desi Dwi. 2018. “Towards the Westernized Body: A Popular Narrative Reinforced by Men's Lifestyle Magazines in Indonesia." Inter-Asia Cultural Studies 19 (1): 103-116. doi:10.1080/ 14649373.2018.1422351. 
Prianti, Desi Dwi. 2019. "The Identity Politics of Masculinity as a Colonial Legacy." Journal of Intercultural Studies 40 (6): 700-719. doi:10.1080/07256868.2019.1675612.

Prihatin, Intan Umbari. 2016. "Angelina Seperti Debu di Bawah Keset Nazaruddin." Merdeka.com, January 6.

Rahayu, Mundi. 2014. "Muslim Women Identity in Consumer Society: A Critical Discourse Analysis on the Hijabers Community." Presented at Goettingen International Summer School on Multiple Modernities, Germany, August 2014.

Risberg, Annette, Janne Tienari, and Eero Vaara. 2003. "Making Sense of A Transnational Merger: Media Texts and the (Re) Construction of Power Relations." Culture and Organization 9 (2): 121-137. doi:10.1080/14759550302806.

Sandman, Tua. 2021. "Familiar Felons: Gendered Charactherisations and Narrative Tropes in Media Representations of Offending Women 1905-2015." Crime, Media, Culture 1-23.

Savitri Hartono, Hanny. 2018. "Virtually (Im) Moral: Pious Indonesian Muslim Women's Use of Facebook." Asian Studies Review 42 (1): 39-52. doi:10.1080/10357823.2017.1407290.

Sindonews. 2020. "Korupsi Dan Modifikasi Visual." November 25.

Smyth, Ines. 1991. "The Indonesian Family Planning Programme: A Success Story for Women?" Development and Change 22 (4): 781-805. doi:10.1111/j.1467-7660.1991.tb00434.x.

Stensöta, Helena, and Lena Wängnerud. 2018. "Why Expect a Link between Gender and Corruption?" In Gender and Corruption: Historical Roots and New Avenues for Research, edited by Helena Stensöta and Lena Wängnerud, 3-20. UK: Palgrave Macmillan.

Sung, Hung-En. 2003. "Fairer Sex or Fairer System? Gender and Corruption Revisited." Social Forces 82 (2): 703-723. doi:10.1353/sof.2004.0028.

Suryakusuma, Julia I. 1996. "The State and Sexuality in New Order Indonesia." In Fantasizing the Feminine in Indonesia, edited by Laurie J. Sears, 92-119. United States: Duke University Press.

Swamy, Anand, Stephen Knack, Young Lee, and Omar Azfar. 2001. "Gender and Corruption." Journal of Development Economics 64 (1): 25-55. doi:10.1016/S0304-3878(00)00123-1.

Tania Murray, Li. 2016. "Governing Rural Indonesia: Convergence on the Project System." Critical Policy Studies 10 (1): 79-94. doi:10.1080/19460171.2015.1098553.

Torsello, Davide, and Bertrand Venard. 2016. "The Anthropology of Corruption." Journal of Management Inquiry 25 (1): 34-54. doi:10.1177/1056492615579081.

van Zoonen, Liesbet. 1994. Feminist Media Studies. London: Sage.

Walton, G W., and Jon S.T. Quah. 2016. "Silent Screams and Muffled Cries: The Ineffectiveness of Anti-corruption Measures in Papua New Guinea." Asian Education and Development Studies 5 (2): 211-226. doi:10.1108/AEDS-01-2016-0005.

Wang, Qi. 2006. "Gender, Corruption, and Anti-Corruption in China." Asia Insights 2: 13.

Wang, Qi, and Dongchao Min. 2014. "Gender and Corruption - Insights from China." In The Quandaries of China's Domestic and Foreign Development, edited by Dominik Mierzejewski, 11-28. Łódź, Poland: Publishing House of the University of Łódź.

Watson, David, and Amy Moreland. 2014. "Perceptions of Corruption and the Dynamics of Women's Representation." Politics \& Gender 10 (3): 392-412. doi:10.1017/S1743923X14000233.

World Bank. 2003. Combating Corruption In Indonesia: Enhancing Accountability For Development. Washington, DC: The World Bank.

Wulandari, Erni, and Rini Fidiyani. 2018. "Criticism of the Juridical Positivism Paradigm on the Meaning of Pornography in the Judge Mindset." SHS Web of Conferences. 54:4. Proceeding of the 1st International Conference on Law, Governance and Social Justice, 25-26 September 2018, Purwokerto, Indonesia. doi:10.1051/shsconf/20185407002. 